\title{
Surface Ectoderm
}

National Cancer Institute

\section{Source}

National Cancer Institute. Surface Ectoderm. NCI Thesaurus. Code C34309.

The outermost part of the ectoderm, making it the most superficial of three primary germ layers in the early embryo. It differentiates to form the epidermis and its appendages, the stratified epithelia, the cells that form the lens and cornea of the eye, and the dental enamel. 